\title{
Effect of temperature degrees on the duration of the phytophagous mite, Eutetranychus orientalis complex (klein) (acari: Tetranychidae) when fed on green bean (Phaseolus vulgaris L.)
}

\author{
A. M. Metwally, A. A. Abdallah and M. A. Abd El-Hady * \\ Department of Zoology and Nematology, Faculty of Agriculture, Al-Azhar University, Cairo, Egypt \\ * Corresponding author E-mail: Mohamed-abdelhady. 5@azhar.edu.eg (M. Abd El-Hady).
}

\begin{abstract}
Spider mites (Acari: Tetranychidae) are the most important phytophagous mite pests of agricultural crops over the worldwide. This study aims to study the effect of different temperature degrees on the developmental stages of the phytophagous mite Eutetranychus orientalis complex (Klein) on some vegetable crops and to predict the population according to the prevailing temperature. Development times of the Eutetranychus orientalis complex (Klein) were evaluated in the laboratory on excised leaf disc of (green bean) Phaseolus vulgaris L at various degrees of temperature $\left(20,25\right.$ and $30 \pm 2{ }^{\circ} \mathrm{C}$ ) with $60 \pm 5 \%$ relative humidity $(\mathrm{RH})$ under laboratory conditions. Total development times from egg to adult stage were $26.37 \pm 1.28$ and $24.24 \pm 0.92$ days at $20 \pm 2{ }^{\circ} \mathrm{C}, 21.25 \pm 1.23$ and $18.99 \pm 1.28$ days at $25 \pm 2{ }^{\circ} \mathrm{C}$ and $11.48 \pm 1.07$ and $9.88 \pm 1.16$ at $30 \pm 2{ }^{\circ} \mathrm{C}$ for female and male respectively. The preoviposition_period, oviposition period and post-oviposition period were $4.96 \pm 1.44,8.13 \pm 2.22$ and $4.87 \pm 1.23$ days at $20 \pm 2{ }^{\circ} \mathrm{C}, 1.46 \pm 0.35,6.73 \pm 0.82$ and $1.99 \pm 0.79$ days at $25 \pm 2{ }^{\circ} \mathrm{C}$ and $1.04 \pm 0.27,6.20 \pm 0.87$ and $1.67 \pm 0.40$ days respectively at $30 \pm 2{ }^{\circ} \mathrm{C}$. Total eggs laid by mite were found to reach the maximum limit at $30 \pm 2{ }^{\circ} \mathrm{C}(22.60 \pm 3.63$ eggs $/ \mathrm{mite})$ followed by $25 \pm 2{ }^{\circ} \mathrm{C}(16.44 \pm 3.87 \mathrm{eggs} / \mathrm{mite})$ and $20 \pm 2{ }^{\circ} \mathrm{C}(3.14 \pm 2.56 \mathrm{eggs} / \mathrm{mite})$. In conclusion, the time required for female life cycle, longevity and life span was longer than the male at different tested temperature degrees and the differences were significant and the $20 \pm 2^{\circ} \mathrm{C}$ gave the longest life cycle, while the temperature of $30 \pm 2^{\circ} \mathrm{C}$ gave the shortest life cycle.
\end{abstract}

Keywords: Phytophagous mite; Eutetranychus orientalis Complex; Tetranychidae.

\section{INTRODUCTION}

Spider mites (Acari: Tetranychidae) are the most important phytophagous mite pests of agricultural crops over the worldwide, whose population outbreaks can cause serious damage and yield losses. Among them, the citrus brown mite, Eutetranychus orientalis (Klein), is especially significant as the most polyphagous species in field and greenhouses in the Middle East, Africa, and Asia. It represents a serious pest of a wide variety of agricultural, ornamental and medicinal plants (Rasmy, 1978; Dhooria, 1985; Gupta, 1985; Kandeel et al., 1986; Sewify and Mabrouk 1991; Sangeetha and Ramani, 2011; El-Sharabasy, 2015).

The oriental red mite, E. orientalis (Klein) (Acarina: Tetranychidae), is not only a principal pest of citrus, but also has been reported to attack a wide variety of other plants including Albizia spp. (Walter et al., 1995).

The infested leaves turn yellowish-brown, dry up and ultimately fall off. Mite infestation is usually seen on the upper surface of leaves, under heavy webs to which dust particles adhere.

The infested leaves also get crumpled. Web formation, adhered dust particles and continuous cell sap sucking badly affect the photosynthesis process, leading to retarded growth and reduced vigour of the host plants (Yousef et al., 2006).

In Spain, E. orientalis was observed for the first time in Malaga province, from where it extended towards nearby areas. The primary host of E. orientalis is Citrus spp., although it can cause damages to more than 50 plant species, so it is one of the most important pests due to its great colonisation ability. Several phytosanitary treatments per year are usually required to control it (Jeepson, 1989; Walter et al., 1995; García, 2003).

This study aims to study the effect of different temperature degrees on the developmental stages of the phytophagous mite Eutetranychus orientalis complex (Klein) on some vegetable crops and to predict the population according to the prevailing temperature.

\section{MATERIALS AND METHODS}

In this study, we evaluated the effects of various degrees of temperature $(20,25$ and $30 \pm 2$ $\left.{ }^{\circ} \mathrm{C}\right)$ with $60 \pm 5 \%$ R.H on the duration of $E$. orientalis complex (Klein) reared on leaves of (green bean) Phaseolus vulgaris L.

P. vulgaris leaves cultures are prepared as follows; A young but full-grown primary vegetables leaf with a short piece of the petiole was pressed firmly, with the upper surface uppermost, on wad of wet cotton wool 
contained in a tin foil-dish to prepare pure culture of the tested mite. All the leaves used for the experiments were collected and placed in water containing a drop of dish detergent, rinsed several times with water, and examined under a stereozoom microscope to assure that no other mites were present.

Leaf discs of $2.5 \mathrm{~cm}$ in diameter were put in tin foil-dishes $(15 \mathrm{~cm}$ in depth and $20 \mathrm{~cm}$ in diameter) on a piece of cotton wool. Each disc was rounded with a layer of cotton wetted with water. Drops of water were daily added to maintain suitable moisture for the mite. Whenever, a leaf substrate began to deteriorate, it was replaced with another fresh one. Twenty discs of fresh leaves of vegetables leaf each foildish contained ten discs.

The adult females were put with adult males, and each pair was allowed $24 \mathrm{~h}$ for mating. Then the males were removed. Such females were allowed $24 \mathrm{~h}$ for egg laying, then removed to fresh leaves and so on to obtain larvae of known age. The observations were inspected twice daily and the duration of developmental stages including egg incubation, immature stages, life cycle, longevity and fecundity were recorded. The rearing experiment was carried at 20, 25 and $30 \pm 2^{\circ} \mathrm{C}$. and $60 \pm 5 \%$ R.H.

\section{Statistical Analysis}

Data was subjected to analysis of variance (ANOVA) using Completely Randomized Design (CRD). We compared the obtained mean values for developmental parameters on (green bean) Phaseolus vulgaris L. at three different temperature degrees $(20,25$ and $\left.30 \pm 2^{\circ} \mathrm{C}\right)$.

\section{RESULTS}

We studied the development of Eutetranychus orientalis complex (Klein) at 20, 25 and $30 \pm 2{ }^{\circ} \mathrm{C}$, with $60 \pm 5 \%$ R.H. on leaves of (green bean) $P$. vulgaris L.

The eggs of E. orientalis complex (Klein) hatched after $9.34 \pm 0.24,7.99 \pm 0.38$ and $4.80 \pm 0.30$ days at 20,25 and $30 \pm 2^{\circ} \mathrm{C}$. and $60 \pm 5 \%$ R.H., respectively for female (Figure 1), while it was $9.27 \pm 0.50,7.67 \pm 0.40$ and $4.34 \pm 0.33$ days at 20,25 and $30 \pm 2{ }^{\circ} \mathrm{C}$ with $60 \pm 5 \%$ R.H., on the same trend for male on (green bean) P. vulgaris L. leaves (Figure 2). There was significant difference between the tested temperature as shown in (Table 1).

The average period of active larva (Table (1), Figs. (1 and 2 ) lasted for $4.17 \pm 0.43,3.90 \pm 0.36$ and $1.56 \pm 0.27$ days for female, while it was
$3.89 \pm 0.41,3.66 \pm 0.26$ and $1.39 \pm 0.29$ days for male at 20,25 and $30 \pm 2{ }^{\circ} \mathrm{C}$ with $60 \pm 5 \%$ R.H., respectively.

The average period of quiescent stage lasted $2.31 \pm 0.53,1.63 \pm 0.29$ and $0.63 \pm 0.29$ days for female and $2.10 \pm 0.35,1.33 \pm 0.26$ and $0.47 \pm 0.23$ days for male at 20,25 and $30 \pm 2{ }^{\circ} \mathrm{C}$ with $60 \pm 5 \%$ R.H., respectively. The total larval periods were $6.50 \pm 0.67,5.53 \pm 0.59$ and $2.19 \pm 0.43$ days for female, while it was 5.99 $\pm 0.61,4.99 \pm 0.37$ and $1.86 \pm 0.32$ days for male at the same trend. The differences between the periods of larval stages were significant for all tested temperatures, the longest period was at $20 \pm 2{ }^{\circ} \mathrm{C}$, while the shortest period was at $30 \pm 2{ }^{\circ} \mathrm{C}$ on (green bean) $P$. vulgaris L. leaves. (Table 1 ), and Figures 1 and 2).

The active female protonymph (Table 1) lasted for $2.63 \pm 0.42,2.31 \pm 0.34$ and $1.83 \pm 0.26$ days, while the quiescent stage lasted for $1.89 \pm 0.33,1.43 \pm 0.31$ and $0.87 \pm 0.33$ days at 20,25 and $30 \pm 2^{\circ} \mathrm{C}$ with $60 \pm 5 \%$ R.H., respectively.

The active male protonymph lasted $2.36 \pm 0.36,1.80 \pm 0.21$ and $1.54 \pm 0.30$ days while the quiescent stage lasted $1.49 \pm 0.49,1.24 \pm 0.24$ and $0.65 \pm 0.32$ days at the same trend.

The total protonymphal period was $4.56 \pm 0.61,3.74 \pm 0.48$ and $2.70 \pm 0.51$ days for female, while it was $3.84 \pm 0.68,3.04 \pm 0.36$ and $2.19 \pm 0.44$ days for male at the same trend (Figures, 1 and 2).

The previous data show that there were significant differences between the effects of the three different temperatures on (green bean) $P$. vulgaris $\mathrm{L}$. leaves on the protonymphal periods.

The active female deutonymph occupied $3.39 \pm 0.34,2.30 \pm 0.28$ and $1.04 \pm 0.31$ days, while the quiescent stage occupied 2.50 \pm 0.27 , $1.69 \pm 0.23$ and $0.75 \pm 0.25$ days at 20, 25 and $30 \pm 2{ }^{\circ} \mathrm{C}$ and $60 \pm 5 \%$ R.H., but active male deutonymph occupied $2.89 \pm 0.41,1.90 \pm 0.28$ and $0.85 \pm 0.32$ days; the quiescent stage lasted $1.99 \pm 0.50,1.39 \pm 0.25$ and $0.65 \pm 0.20$ days at 20,25 and $30 \pm 2^{\circ} \mathrm{C}$ and $60 \pm 5 \%$ R.H., respectively (Table $1)$, and Figures 1 and 2).

The total deutonymphal periods were $5.89 \pm 0.55,3.99 \pm 0.32$ and $1.79 \pm 0.50$ days for female, while such periods were $4.88 \pm 0.72$, $3.29 \pm 0.50$ and $1.49 \pm 0.50$ days for male at the same trend. The previous data show that there was significant difference among the tested temperatures.

The total female immature stage which included larval, protonymphal and deutonymphal stages lasted for $17.07 \pm 1.24$, 
$13.26 \pm 0.98$ and $6.68 \pm 0.85$ days (Table 1 ), while those of male lasted $14.97 \pm 0.75,11.32 \pm 1.00$ and $5.55 \pm 0.99$ days, at 20,25 and $30 \pm 2{ }^{\circ} \mathrm{C}$ and $60 \pm 5 \%$ R.H., respectively Figs. (1 and 2).

In general, the time required for female immature stage was longer than that of male at different tested temperatures and the differences were significant as shown in (Table 1).

The period of life cycle of E. orientalis complex (Klein), which included incubation, larval, protonymphal and deutonymphal stages was completed in $26.37 \pm 1.28,21.25 \pm 1.23$ and $11.48 \pm 1.07$ days for female, while it was $24.24 \pm 0.92,18.99 \pm 1.28$ and $9.88 \pm 1.16$ days for male at 20,25 and $30 \pm 2{ }^{\circ} \mathrm{C}$ and $60 \pm 5 \%$ R.H. on (green bean) Phaseolus vulgaris L leaves, respectively.

In general, it can be concluded conclusion the $20 \pm 2{ }^{\circ} \mathrm{C}$ gave the longest life cycle and the differences among the three temperatures were highly significant (Table 1, and Figures 1 and 2).

The longevity period average (Table 1) lasted for $19.31 \pm 2.48,10.18 \pm 1.44$ and $8.91 \pm 0.84$ days for female while it was $12.85 \pm 1.29$, $6.02 \pm 0.66$ and $4.75 \pm 0.65$ days for male at 20,25 and $30 \pm 2{ }^{\circ} \mathrm{C}$ and $60 \pm 5 \%$ R.H., on (green bean) $P$. vulgaris $\mathrm{L}$. leaves at the same trend.

The life span average (Table 1) which included the period of life cycle and longevity was $45.68 \pm 3.20,31.43 \pm 2.18$ and $20.39 \pm 1.36$ days for female while it was $37.09 \pm 1.49,25.01 \pm 0.90$ and 14.64 \pm 1.22 days for male at 20, 25 and $30 \pm 2^{\circ} \mathrm{C}$. and $60 \pm 5 \%$ R.H., when all the individual reread on the leaves of (green bean) $P$. vulgaris L. (Figures, 1 and 2).

In general, the time required for female life cycle, longevity and life span was longer than the male at different tested temperature degrees and the differences were significant as shown in Table 1).

The preoviposition, generation, oviposition and postoviposition period (Table 2, Figure, 3), averaged $4.96 \pm 1.44,31.20 \pm 1.98,8.13 \pm 2.22$ and $4.87 \pm 1.23$ days respectively at $20 \pm 2{ }^{\circ} \mathrm{C}$. with $60 \pm 5 \%$ R.H., while it was $1.46 \pm 0.35,22.71 \pm 1.27$, $6.73 \pm 0.82$ and $1.99 \pm 0.79$ days at the same trend at $25 \pm 2{ }^{\circ} \mathrm{C}$ with $60 \pm 5 \%$ R.H., while it was $1.04 \pm 0.27,17.41 \pm 1.66,6.20 \pm 0.87$ and $1.67 \pm 0.40$ at $30 \pm 2{ }^{\circ} \mathrm{C}$ with $60 \pm 5 \%$ R.H., when all the individuals were reread on the leaves of (green bean) P. vulgaris L.

The female average number of egg was $3.14 \pm 2.56,16.44 \pm 3.87$ and $22.60 \pm 3.63$ at 20,25 and $30 \pm 2^{\circ} \mathrm{C}$. and $60 \pm 5 \%$ R.H., when the individual was reread on the leaves of (green bean) P. vulgaris L. respectively. The previous data point out that there were significant differences between the effects of different tested temperature degrees as shown in (Table 2) and Figure 3).

\section{DISCUSSION}

The previous results agree with Abd ElRahman (1996), El-Moghazy (2006) and Sangeetha et al. (2013) in laboratory studies on the phytophagous mite, Eutetranychus orientalis complex (klein) (Acari: Tetranychidae). The phytophagous mite species passed through one larval and two nymphal stages before being adults.

Childers et al. (2009) examined the life history of the phytophagous mite, Eutetranychus banksi (McGregor) at various degrees of temperature, females of Eutetranychus banksi developed from egg to adult in 29.6, 17.2, 13.1, 11.6, 11.7 and 9.6 days compared to 27.7, 16.4, 12.0, 10.1, 10.8 and 8.5 days for males at 15, 20, 25, 28, 30 and $32{ }^{\circ} \mathrm{C}$. respectively. Developmental times between the both sexes were significantly different $(\mathrm{P}<0.05)$ at each temperature. Mites were reared on whole leaf arenas of Citrus paradisi Macf.

\section{CONCLUSON}

In general, it can be concluded that, the time required for female life cycle, longevity and life span was longer than the male at different tested temperature degrees and the differences were significant and the temperature of $20 \pm 2^{\circ} \mathrm{C}$ gave the longest life cycle, while the temperature of $30 \pm 2{ }^{\circ} \mathrm{C}$ gave the shortest life cycle.

\section{REFERENCES}

Abdel-Rahman, S., 1996. Studies on Some Tetranychoid Mites. Ph.D. Thesis, Fac. Agric., Cairo Univ., Egypt, p. 118

Childers, C.C., Abou-Setta, M.M., Nawar, M.S., 2009. Biology of Eutetranychus banksi life tables on 'Marsh' grapefruit leaves at different temperatures (Acari: Tetranychidae). Int. J. Acarol., 17 (1), 29-35.

Dhooria, M.S., 1985. Development of citrus mite, Eutetranychus orientalis (Acari: Tetranychidae) as influenced by age and surface of leaves of different hosts. Ind. J. Acarol., 9, 82-88.

El-Moghazy, M.M.E., 2006. Ecological, Taxonomical and Biological Studies on Some Economic Mites. Ph.D. Thesis, Fac. Agric., Al-Azhar Univ., Cairo, Egypt, p. 206.

El-Sharabasy, H.M., 2015. Laboratory evaluation of the effect of the entomopathogenic fungi, Hirsutella thompsonii and Paecilomyces fumosoroseus, against the 
citrus brown mite, Eutetranychus orientalis (Acari: Tetranychidae). Plant Protect. Sci., 51, 39-45.

García. E., Márquez, A.L., Orta, S., Alvarado, P., 2003. Characterization of the presence of Eutetranychus banksi (McGregor) and Eutetranychus orientalis (Klein) in southern Spain. Phytoma 153, 90-06. (In Spanish).

Gupta, S.K., 1985. Handbook: Plant mites of India. Sri Aurobindo press, Calcutta, India. p.520.

Jeepson, L.R., 1989. Biology of citrus insects, mites and molluscs. In: The citrus industry. Ed. W. Reuther, E.C. Calava and G.E. Carman, Division of Agriculture and Natural Reseourses. Oaklandl, California.

Kandeel, M.M.H., Rakha, M.A., El-Halaeany, M.E., 1986. Citrus mites in Egypt. Agric. Res. Rev., 64 (1), 132-127.

Rasmy, A.H., 1978. Biology of citrus brown mite, Eutetranychus orientalis (Klein) as affected by some citrus species. Acarologia, 19 (2), 222-224.
Sangeetha, G.K., Ramani, N., 2011. Feeding strategies of Eutetranychus orientalis (Klein) (Acari: Tetranychidae) on Moringa oleifera. Lam. Hexapoda, 18 (1), 76-79.

Sangeetha, G.K., Athira, A., Aswathi, S.B., Fathima S., Jishna, M.P., Akshaya, A., 2013. Breeding Strategies of Eutetranychus rientalis (Klein) (Acari: Tetranychidae) On Neem. Int. J. Sci. Nat., 4(3), 468-472.

Sewify, G.H., Mabrouk, A.M., 1991. The susceptibility of different stages of the citrus brown mite Eutetranychus orientalis (Klein) (Acarina: Tetranychidae) to the entomopathogenic fungus Verticillium lecanii (Zimm) Viegas. Egypt J. Appl. Biol. Cont. 1, 89-92.

Walter, D.E., Halliday, R., Smith, D., 1995. The oriental red mite, Eutetranychus orientalis (Klein) (Acarina: Tetranychidae), in Australia. Aust. J. Entomol., 34, 307308.

Yousef, M., Chouhan, S., Guptan, R.K., 2006. Loss assessment in some important forest tree species, caused by Eutetranychus orientalis (Klein) (Acarina: Tetranychidae). Bull. Pure Appl. Sci., 25, 25-30. 
Table 1. Effect of temperature on duration of egg incubation period and life cycle of Eutetranychus orientalis complex (Klein) (female and male) reared on (green bean) Phaseolus vulgaris L. at 20, 25 and $30 \pm 2{ }^{\circ} \mathrm{C}$, with $60 \pm 5 \%$ R.H.

\begin{tabular}{|c|c|c|c|c|c|}
\hline \multirow{2}{*}{ Stages } & \multirow{2}{*}{$\operatorname{sex}$} & \multicolumn{3}{|c|}{ Mean duration in days } & \multirow{2}{*}{$\begin{array}{c}\text { LSD } \\
0.05 \%\end{array}$} \\
\hline & & $20^{\circ} \pm 2$ & $25^{\circ} \pm 2$ & $30^{\circ} \pm 2$ & \\
\hline \multirow{2}{*}{ Incubation period } & q & $9.34 \pm 0.24 \mathrm{a}$ & $7.99 \pm 0.38 \mathrm{~b}$ & $4.80 \pm 0.30 \mathrm{c}$ & 0.286 \\
\hline & $\hat{\sigma}$ & $9.27 \pm 0.50 \mathrm{a}$ & $7.67 \pm 0.40 \mathrm{~b}$ & $4.34 \pm 0.33 c$ & 0.381 \\
\hline \multirow{2}{*}{ Active larva } & q & $4.17 \pm 0.43 \mathrm{a}$ & $3.90 \pm 0.36 \mathrm{a}$ & $1.56 \pm 0.27 \mathrm{~b}$ & 0.329 \\
\hline & $\hat{0}$ & $3.89 \pm 0.41 \mathrm{a}$ & $3.66 \pm 0.26 \mathrm{a}$ & $1.39 \pm 0.29 b$ & 0.305 \\
\hline \multirow{2}{*}{ Quiescent larva } & q & $2.31 \pm 0.53 \mathrm{a}$ & $1.63 \pm 0.29 b$ & $0.63 \pm 0.29 c$ & 0.353 \\
\hline & $\hat{\sigma}$ & $2.10 \pm 0.35 a$ & $1.33 \pm 0.26 \mathrm{~b}$ & $0.47 \pm 0.23 c$ & 0.264 \\
\hline \multirow{2}{*}{ Total Larval stage } & q & $6.50 \pm 0.67 \mathrm{a}$ & $5.53 \pm 0.59 b$ & $2.19 \pm 0.43 c$ & 0.527 \\
\hline & $\delta^{\lambda}$ & $5.99 \pm 0.61 \mathrm{a}$ & $4.99 \pm 0.37 \mathrm{~b}$ & $1.86 \pm 0.32 \mathrm{c}$ & 0.416 \\
\hline \multirow{2}{*}{ Active Protonymph } & q & $2.63 \pm 0.42 a$ & $2.31 \pm 0.34 \mathrm{~b}$ & $1.83 \pm 0.26 c$ & 0.318 \\
\hline & $\hat{\sigma}$ & $2.36 \pm 0.36 \mathrm{a}$ & $1.80 \pm 0.21 \mathrm{~b}$ & $1.54 \pm 0.30 \mathrm{~b}$ & 0.273 \\
\hline \multirow{2}{*}{ Quiescent Protonymph } & q & $1.89 \pm 0.33 \mathrm{a}$ & $1.43 \pm 0.31 \mathrm{~b}$ & $0.87 \pm 0.33 c$ & 0.297 \\
\hline & $\hat{\sigma}$ & $1.49 \pm 0.49 a$ & $1.24 \pm 0.24 \mathrm{~b}$ & $0.65 \pm 0.32 c$ & 0.333 \\
\hline \multirow{2}{*}{ Total Protonymphal stage } & q & $4.56 \pm 0.61 \mathrm{a}$ & $3.74 \pm 0.48 \mathrm{~b}$ & $2.70 \pm 0.51 c$ & 0.490 \\
\hline & $\hat{0}$ & $3.84 \pm 0.68 \mathrm{a}$ & $3.04 \pm 0.36 \mathrm{~b}$ & $2.19 \pm 0.44 c$ & 0.460 \\
\hline \multirow{2}{*}{ Active Deutonymph } & q & $3.39 \pm 0.34 \mathrm{a}$ & $2.30 \pm 0.28 \mathrm{~b}$ & $1.04 \pm 0.31 \mathrm{c}$ & 0.284 \\
\hline & $\hat{0}$ & $2.89 \pm 0.41 \mathrm{a}$ & $1.90 \pm 0.28 \mathrm{~b}$ & $0.85 \pm 0.32 c$ & 0.318 \\
\hline \multirow{2}{*}{ Quiescent Deutonymph } & q & $2.50 \pm 0.27 \mathrm{a}$ & $1.69 \pm 0.23 b$ & $0.75 \pm 0.25 c$ & 0.231 \\
\hline & $\sigma^{\lambda}$ & $1.99 \pm 0.50 \mathrm{a}$ & $1.39 \pm 0.25 b$ & $0.65 \pm 0.20 c$ & 0.315 \\
\hline \multirow{2}{*}{ Total Deutonymphal stage } & q & $5.89 \pm 0.55 a$ & $3.99 \pm 0.32 b$ & $1.79 \pm 0.50 \mathrm{c}$ & 0.427 \\
\hline & 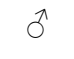 & $4.88 \pm 0.72 \mathrm{a}$ & $3.29 \pm 0.50 \mathrm{~b}$ & $1.49 \pm 0.50 \mathrm{c}$ & 0.539 \\
\hline \multirow{2}{*}{ Immature stage } & q & $17.07 \pm 1.24 \mathrm{a}$ & $13.26 \pm 0.98 b$ & $6.68 \pm 0.85 c$ & 0.949 \\
\hline & $\sigma^{\pi}$ & $14.97 \pm 0.75 a$ & $11.32 \pm 1.00 \mathrm{~b}$ & $5.55 \pm 0.99 c$ & 0.851 \\
\hline \multirow{2}{*}{ Life cycle } & q & $26.37 \pm 1.28 \mathrm{a}$ & $21.25 \pm 1.23 \mathrm{~b}$ & $11.48 \pm 1.07 \mathrm{c}$ & 1.098 \\
\hline & $\hat{0}$ & $24.24 \pm 0.92 \mathrm{a}$ & $18.99 \pm 1.28 \mathrm{~b}$ & $9.88 \pm 1.16 c$ & 1.034 \\
\hline \multirow{2}{*}{ Longevity } & q & $19.31 \pm 2.48 \mathrm{a}$ & $10.18 \pm 1.44 \mathrm{~b}$ & $8.91 \pm 0.84 \mathrm{~b}$ & 1.581 \\
\hline & $\hat{0}$ & $12.85 \pm 1.29 \mathrm{a}$ & $6.02 \pm 0.66 \mathrm{~b}$ & $4.75 \pm 0.65 c$ & 0.850 \\
\hline \multirow{2}{*}{ Life span } & q & $45.68 \pm 3.20 \mathrm{a}$ & $31.43 \pm 2.18 \mathrm{~b}$ & $20.39 \pm 1.36 c$ & 2.173 \\
\hline & $0^{\lambda}$ & $37.09 \pm 1.49 a$ & $25.01 \pm 0.90 \mathrm{~b}$ & $14.64 \pm 1.22 \mathrm{c}$ & 1.118 \\
\hline
\end{tabular}

Means in the same coulomb not followed by the same letter are significantly different $(\mathrm{P}<0.05)$. 


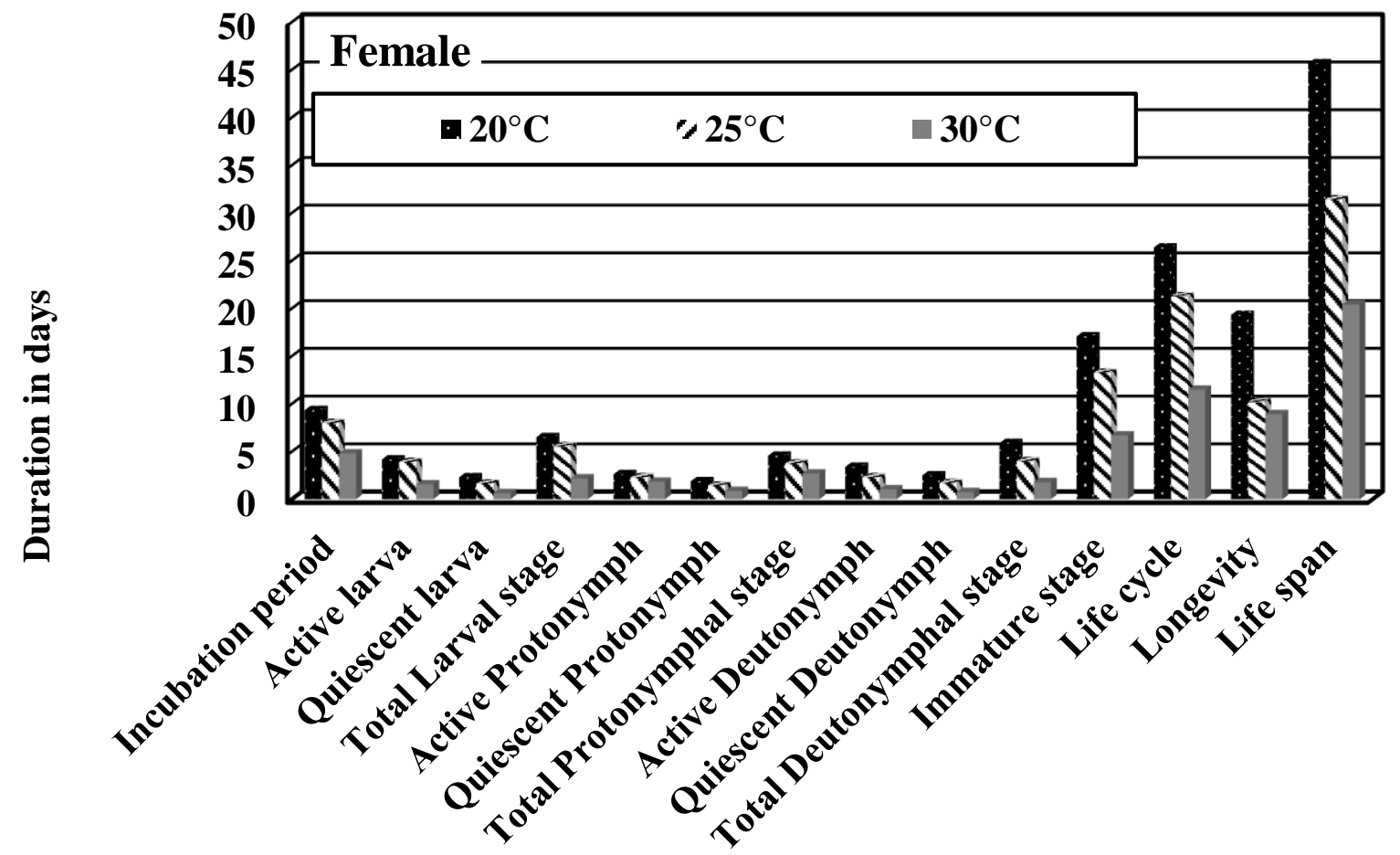

Fig. 1. The effect of different temperature degrees on female development of Eutetranychus orientalis complex (Klein) on (green bean) Phaseolus vulgaris L.

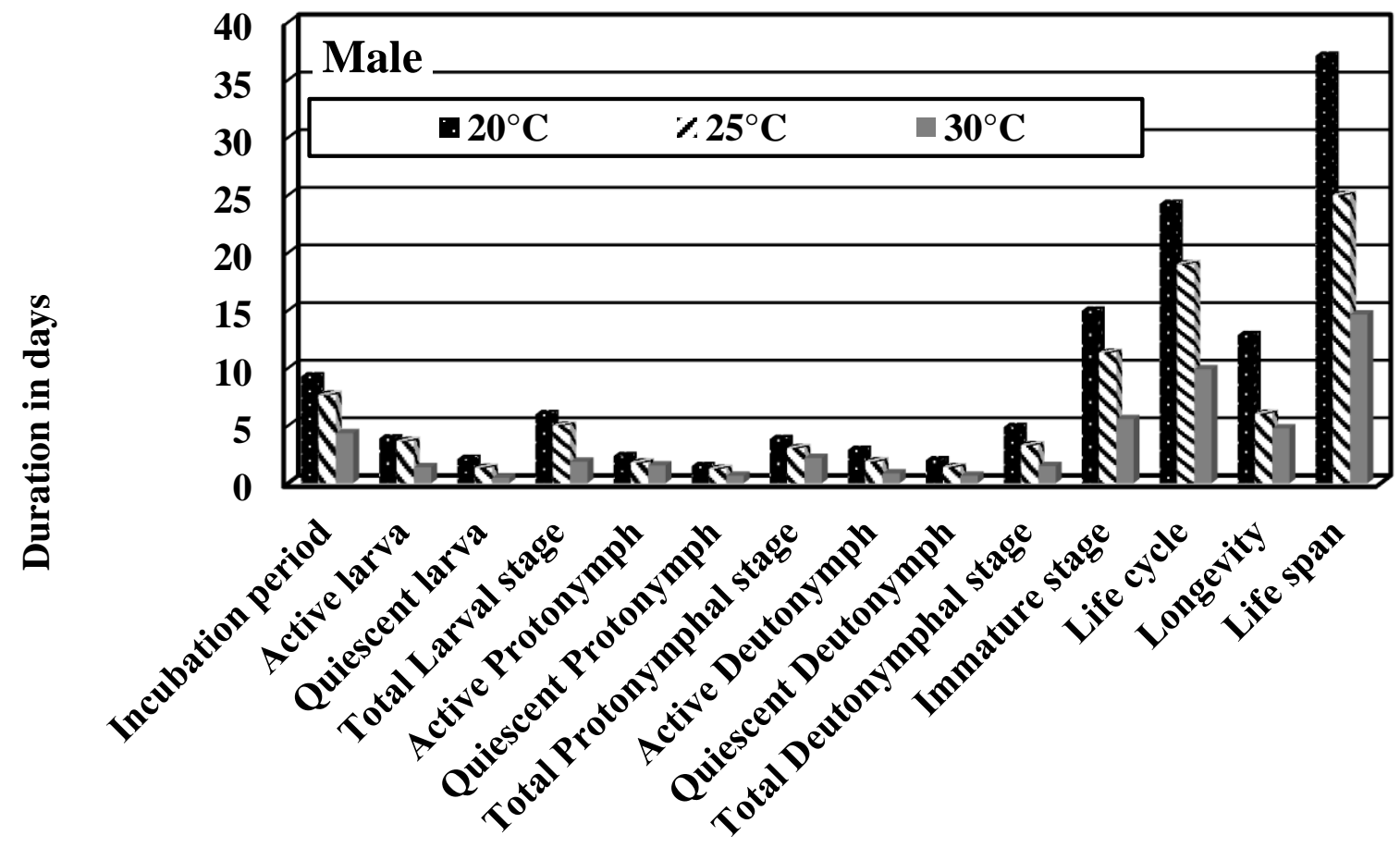

Fig. 2. The effect of different temperature degrees on male development of Eutetranychus orientalis complex (Klein) on (green bean) Phaseolus vulgaris L. 
Table 2. Effect of temperature on longevity, life span and fecundity of Eutetranychus orientalis complex (Klein) (female) reared on (green bean) Phaseolus vulgaris L. at 20, 25 and $30 \pm 2{ }^{\circ} \mathrm{C}$ with $60 \pm 5$ $\%$ R.H.

\begin{tabular}{lcccc}
\hline \multicolumn{1}{c}{ Stages } & \multicolumn{3}{c}{ Mean duration in days } & \multicolumn{1}{c}{ LSD 0.05\% } \\
\hline Pre oviposition & $4.96 \pm 1.44 \mathrm{a}$ & $1.46 \pm 0.35 \mathrm{~b}$ & $1.04 \pm 0.27 \mathrm{~b}$ & 0.796 \\
Generation & $31.20 \pm 1.98 \mathrm{a}$ & $22.71 \pm 1.27 \mathrm{~b}$ & $17.41 \pm 1.66 \mathrm{c}$ & 1.524 \\
Oviposition & $8.13 \pm 2.22 \mathrm{a}$ & $6.73 \pm 0.82 \mathrm{~b}$ & $6.20 \pm 0.87 \mathrm{~b}$ & 1.333 \\
Post oviposition & $4.87 \pm 1.23 \mathrm{a}$ & $1.99 \pm 0.79 \mathrm{~b}$ & $1.67 \pm 0.40 \mathrm{~b}$ & 0.804 \\
Fecundity & $3.14 \pm 2.56 \mathrm{c}$ & $16.44 \pm 3.87 \mathrm{~b}$ & $22.60 \pm 3.63 \mathrm{a}$ & 3.120 \\
\hline
\end{tabular}

Means in the same coulomb not followed by the same letter are significantly different $(\mathrm{P}<0.05)$.

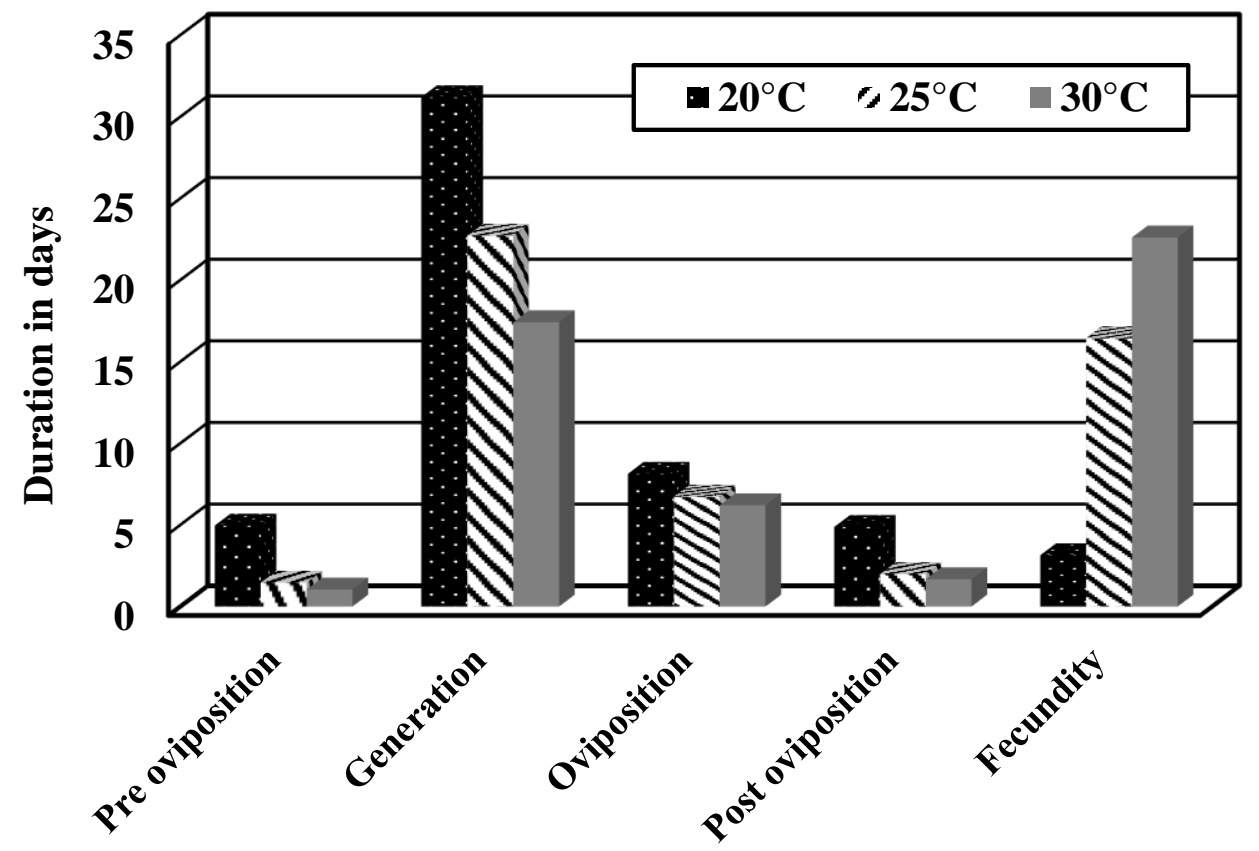

Fig. 3. The effect of different temperature degrees on specific female stages of Eutetranychus orientalis complex (Klein) on (green bean) Phaseolus vulgaris L. 


\section{Eutetranychus orientalis complex (klein) ثاثير درجات الحرارة على مراحل نمو الحلم العنكبوتى (الماهي \\ Phaseolus vulgaris L عند الثذية على أوراق (الفاصوليا الخضراء) (Acari: Tetranychidae) \\ عبد الستار محمد متولي، عوض على عبد الله، محم عبد الهادي حسن عبد الهادي \\ قسم الحيوان الزراعي والنياتودا، كلية الزراعة، جامعة الازهر، القاهرة، مصر}

Mohamed-abdelhady. 5@azhar.edu.eg البريد الإليكتروني للباحث الرئيسي: *

الملخص العربي

الحلم العنكوتى(Acari: Tetranychidae) يعتبر من أهم الآفات الأكاروسية النباتية على مستوى العالم. تهدف هذه الدراسة إلى دراسة تأثير ثلاث من درجات

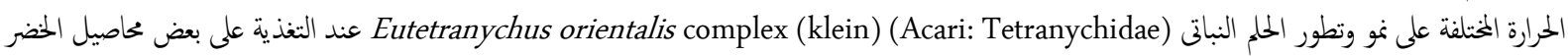

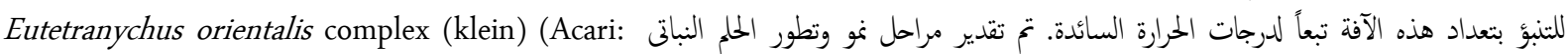
Tetranychidae)

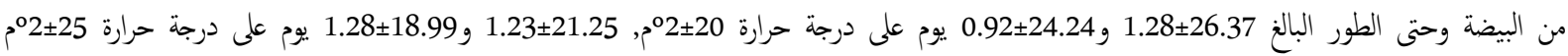

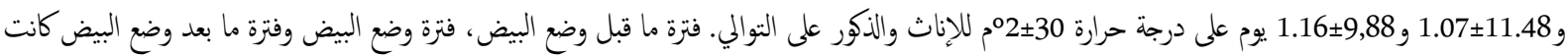

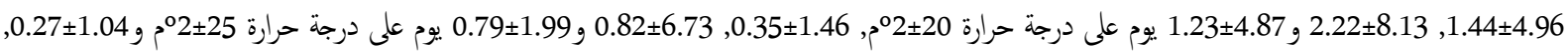

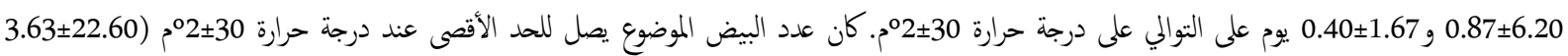

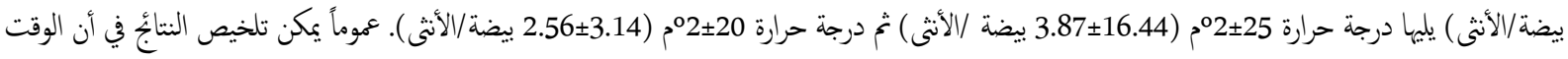

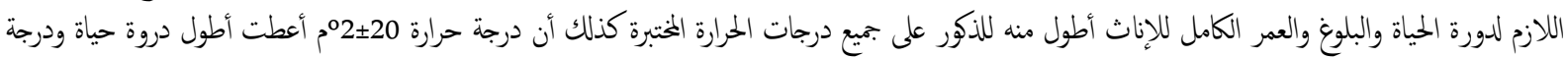

$$
\text { حرارة 30+20 أعطت أقصر دروة حياة. }
$$

الكلمات المثتاحية: سوس نباتي، Complex Eutetranychus orientalis ، Tetranychidae. 